\title{
PENGINTEGRASIAN PENDIDIKAN KARAKTER BERBASIS BUDAYA LOKAL DALAM PEMBELAJARAN KRIYA KAYU PADA SISWA TUNAGRAHITA
}

\author{
Kasiyan dan Agung Sulistyo \\ Unversitas Negeri Yogyakarta \\ email: kasiyan@uny.ac.id
}

\begin{abstract}
Abstrak: Urgensi perihal keberadaan pendidikan karakter terutama terkait nilai-nilai yang berbasis local culture, bukan hanya berlaku bagi anak didik normal, melainkan juga yang berkategori abnormal, misalnya para penyandang tunagrahita, terutama bagi kepentingan pembentukan jiwa nasionalisme dalam dirinya. Terkait dengan hal itu, penelitian ini bertujuan untuk mendeskripsikan pengintegrasian pendidikan karakter berbasis local culture melalui pembelajaran keterampian kriya kayu pada tunagrahita, khususnya yang ada di SLB Negeri 2 Yogyakarta. Penelitian ini menggunakan metode kualitatif-fenomenologis. Data penelitian diperoleh dengan teknik observasi, wawancara, dan dokumentasi. Analisis data menggunakan model interaktif dari Miles dan Huberman. Hasil penelitian dapat disampaikan sebagai berikut. Pengintegrasian pendidikan karakter berbasis local culture melalui pembelajaran keterampian kriya kayu pada tunagrahita dilaksanakan meliputi tahapan: analisis kebutuhan, perencanaan, pelaksanaan, dan evaluasi. Analisis kebutuhan dilakukan dengan teknik wawancara, observasi, dan diskusi dengan guru kelas. Perencanaan pembelajaran dirumuskan menyesuaikan dengan kemampuan siswa penyandang tunagrahita. Pelaksanaan pembelajaran dengan teknik demonstrasi dan project based learning. Evaluasi pembelajaran mencakup proses dan produk. Karya yang dihasilkan berupa hiasan dengan pelbagai ikon ornamen khas Yogyakarta, misalnya lambang kraton, tugu golong-gilig Yogyakarta, sepeda onthel, dan motif batik kawung. Seluruh produk karya seni tersebut, di samping bermakna estetis, juga bermakna filosofis.
\end{abstract}

Kata Kunci: pendidikan karakter, local culture, pembelajaran kriya kayu, siswa tunagrahita

\section{INTEGRATING LOCAL CULTURE BASED- CHARACTER EDUCATION IN WOOD CRAFTS INSTRUCTION FOR MENTALLY RETARDED STUDENTS}

\begin{abstract}
The need to integrate character education concerning values taken from local culture is significant in our educational practices conducted for both the ordinary students and those with special needs, not to mention those of mentally retarded students for the sake of building their nationalism spirit. Regarding this, this particular study aimed to describe the integration of local culture-based character education in the wood crafts instruction for mentally retarded students, particularly the one conducted at SLB Negeri 2 Yogyakarta. This study used phenomenological-qualitative method. Meanwhile, the data for this study were taken from the results of observations, conducting interviews, and documentation. The data were analyzed using the interactive model proposed by Miles and Huberman. The results of the analysis showed that the pactice of integrating local culture-based character education in wood crafts instruction for mentally retarded students in this school was conducted though the steps of conducting needs analysis, planning, doing actions, and evaluation. The needs analysis was conducted by doing interviews, observations and having discussions with the classroom teacher. The planning was formulated by adjusting the students' capability. The teaching and learning process was conducted using the method of demonstration and applying the project based learning. The evaluation involved process and product evaluation. The products were in the form of ornaments with various icons of Yogyakarta, namely, the palace symbol, the special Yogyakarta monument, tugu, golog-gilig, the traditional bicycle onthel, and kawung one of its traditional batik ornaments. The reason of using the icons in these art products is not merely because of its aesthetics but also its underlying philosophy.
\end{abstract}

Keywords: character education, local culture, wood crafts instruction, mentallyretarded students 


\section{PENDAHULUAN}

Pendidikan karakter merupakan salah satu persoalan krusial dan mendasar bagi setiap bangsa termasuk di Indonesia, terutama dalam kaitannya dengan konteks diskursus nasionalisme di tengah arus perubahan zaman di era global (Arnott \& Ozga, 2010; Yama, 2015). Di era globalisasi ketika intensitas kotak dengan pelbagai budaya lain atau asing semakin tinggi, persoalan jati diri atau identitas yang membentuk nasionalisme sebuah bangsa banyak mengalami persoalan, baik dalam wujud kegegaran maupun bahkan kehilangan (Shi, 2013; Steger, Battersby, \& Siracusa, 2014). Padahal, identitas adalah konsep penting, baik dalam konteks masyarakat maupun bangsa (Poole, 2012; Zhuojun \& Hualing, 2014). Tanpa penanda identitas, sebuah masyarakat entah etnik atau bangsa, niscaya tidak akan pernah akan dikenali eksistensinya. Identitas, karenanya betapa selalu menjadi topik penting dan utama bahkan nyaris abadi, yang selalu diperjuangkan untuk diperebutkan di sepanjang sejarah peradaban setiap bangsa (Aguilar, 2000; DeVereaux \& Griffin, 2016). Sementara itu, ketika berbincang perihal identitas sebuah bangsa, di antaranya banyak terkait dengan persoalan pelbagai budaya lokal yang dimilikinya (Robertson \& White, 2003). Oleh karena itu, tak mengherankan bahwa dalam konteks sistem dan praksis pendidikan, perihal risalah identitas yang di antaranya terkait dengan domain pelbagai kultur lokalitas mendapatkan perhatian yang penting untuk disampaikan pada anak didik di segala jenjang dan kategori jenis pendidikan (Sudartini, 2012). Termasuk pula tentunya dalam konteks ini adalah, juga untuk kategori jenis pendidikan khusus atau luar biasa, yang diperuntukkan bagi para penyandang disabilitas (abnormal).

Sebagaimana halnya anak didik yang normal, para penyandang disabilitas juga mempunyai kesetaraan hak dan kewajiban dalam dunia pendidikan, termasuk juga yang berkaitan dengan konten atau muatan nilai-nilai termasuk nasionalisme tentunya (Stebnicki, Marini, \& Graf, 2011; Soldatic \& Grech, 2017) agar menjadi bagian dari warga masyarakat yang beranggung jawab juga bagi keberadaan bangsanya. Salah satu kategori dari penyandang disabilitas adalah yang dinamakan tunagrahita. Penyandang tunagrahita meski mengidap keterbelakangan mental dan mempunyai sifat ketergantungan yang tinggi pada pihak lain, namun sesungguhnya mampu didik dan dilatih. Tunagrahita adalah kondisi individu yang memiliki intelegensi yang signifikan di bawah rata-rata dan disertai dengan ketidakmampuan dalam adaptasi perilaku yang muncul dalam masa perkembangan (Lynn, 2001; Berkson, 2013; Wijaya, 2013).

Penyandang tunagrahita juga identik dengan kepemilikan IQ di bawah rata-rata orang normal (Broman, Nichols, Shaughnessy, et al, 2013), yakni 84 ke bawah berdasarkan tes sebelum usia 16 tahun (Stevens, 2004; Schwitzer \& Rubin, 2012). Berdasarkan Peraturan Pemerintah No. 72 Tahun 1991, penyandang tunagrahita diklasifikasikan menjadi 4 kategori, yakni: tunagrahita ringan (mampu didik) IQ-nya 5070, tunagrahita sedang (mampu latih) IQnya 30-50, dan tunagrahita berat dan sangat berat (mampu rawat) IQ-nya kurang dari 30.

Tunagrahita ringan cenderung memiliki karakteristik pertumbuhan fisik seperti anak normal tetapi kesehatan tubuh dan kematangan motorik lebih lemah dibandingkan dengan anak normal sebayanya (Astati, 2001; Gladfelter \& Barron, 2020). Ciri lainnya adalah, banyak yang lancar berbicara tetapi kurang perbendaharaan kata. Di samping itu, mereka juga meng- 
alami kesulitan berpikir abstrak, tetapi masih mampu mempelajari hal-hal yang bersifat akademiksecara terbatas, misalnya terbatas hanya pada sesuatu yang bersifat konkrit (Rosenberg \& Abbeduto, 2013; Davis \& D'Amato, 2010; Smith, et al. 2002). Gambaran tersebut menunjukkan bahwa tunagrahita ringan memiliki keterbatasan belajar yang cukup kompleks, sehingga peran guru dalam membimbing harus didasarkan pada kemampuan, keterbatasan dan bersifat sangat individual.

Individu dengan kategori tunagrahita ringan mampu dididik dan dilatih, karena perkembangan mental mereka dapat mencapai atau setara dengan anak usia 810 tahun. Dalam kehidupan sosial, penyandan tunagrahita ringan ini, mampu bergaul dan menyesuaikan diri dengan lingkungan sosial dan mampu mengerjakan pekerjaan setingkat semi terampil (Kemendikbud, 2012). Melalui pengawasan dan sedikit perhatian, tunagrahita dapat ditempatkan pada pekerjaan yang sederhana, berulang-ulang, dan tidak membutuhkan banyak berpikir secara kompleks. Hal ini menunjukkan pembelajaran yang tepat bagi tunagrahita ringan, di antaranya adalah jenis pembelajaran yang menekankan pada keterampilan kecakapan hidup yang bersifat vokasional atau kejuruan.

Pembelajaran keterampilan dan kecakapan hidup bagi tunagrahita diperlukan oleh setiap individu, dalam upaya kelangsungan hidupnya (Mastiani \& Suwandari, 2017; Wahyuni, 2018), khususnya lagi ditujukan untuk mendukung kemandirian untuk hidup di tengah masyarakat (Huang \& Cuvo 1997; Mumpuniarti, 2006; Ayres, Lowrey, Douglas, et al, 2011). Melalui keterampilan kejuruan diharapkan anak dapat memperoleh kemampuan yang sesuai dengan bakat dan minat tertentu. Proses pembelajaran model vokasional ini, lebih menekankan pada latihan untuk penguasaan suatu kompetensi suatu bidang tertantu, terutama melalui pelbagai kegiatan yang sifatnya praktik, daripada pembelajaran yang menekankan pada teoretis. Hal ini dikarenakan adanya kecenderungan potensi mentalitas yang dimilikinya yang kurang mampu untuk berpikir abstrak, logis, kurang dapat mengendalikan perasaan, mudah lupa, sulit mengingat istilah, kurang memahami arti istilah, dan daya konsentrasinya kurang baik (Werry \& Aman, 2013; Lubis, Kasih, \& Simatupang, 2019). Keterbatasan kognitif tunagrahita memungkinkan pengaruh terhadap kemampuan motoriknya, sedangkan pembelajaran keterampilan kejuruan lebih banyak praktik yang membutuhkan kemampuan motorik. Maka dari itu, program pembelajaran harus direncanakan secara tepat dengan mempertimbangkan kemampuan dan keterbatasan setiap anak sehingga potensinya dapat dioptimalkan.

Salah satu keterampilan vokasional yang dapat diajarkan kepada penyandang tunagrahita ringan adalah keterampilan kriya kayu, sebagaimana yang memang menjadi muatan kurikulum di sekolah luar biasa (SLB). Adapun salah satu Sekolah Luar Biasa yang juga mengajarkan keterampilan vokasional kriya kayu dan bahkan juga telah mengintegrasikannya dengan muatan nilai-nilai pendidikan karakter yang berbasis budaya lokal, yakni SLB Negeri 2 Yogyakarta. Sekolah ini menangani anak berkebutuhan khusus tunagrahita ringan mulai jenjang TK sampai SMA.

Secara operasional, perihal pengintegrasian muatan lokal dalam program pendidikan, diwujudkan dalam penerjemahan kurikulum lewat praksis pembelajaran yang dikaitkan dengan lingkungan alam, sosial, dan budaya di daerah (Chauvin, 2000; Efendi, 2009). Hal ini sejalan dengan 
pemaknaan kurikulum muatan lokal yang bahan kajiannya diselaraskan dengan kondisi lingkungan atau dareah setempat (Lestari, 2012; Ricci \& Pritscher, 2015). Dalam konteks pelaksanaan pembelajaran keterampilan kriya kayu yang berbasis budaya lokal untuk siswa tunagrahita ringan di SLB Negeri 2 Yogyakarta, dapat disampaikan yakni dengan pengedepanan muatan lokalitas Yogyakarta, terutama dalam kaitannya dengan pembuatan pelbagai produk kriya kayu, misalnya untuk hiasan yang ikon ormanennya diambil dari khas daerah Yogyakarta, misalnya lambang kraton, tugu golong-gilig Yogyakarta, sepeda onthel, motif batik kawung, dan sebagainya.

Secara praksis, pelaksanaan pembelajaran keterampilan kriya kayu yang berbasis budaya lokal untuk siswa tunagrahita ringan di SLB Negeri 2 Yogyakarta tersebut, dibagi menjadi dua bagian, yaitu pembelajaran teori dan praktik, dengan dibantu instrumentasi di antaranya berupa modul dan pelbagai media yang bersifat nyata dan mudah dipelajari oleh siswa, yang berisi pedoman, instruksi, dan isi materi yang dibuat sederhana dan mudah dimengerti. Berdasarkan hasil observasi porduk-produk keterampilan kriya kayu yang dihasilkan oleh siswa tunagrahita ringan di SLB Negeri 2 Yogyakarta tersebut, di samping bervariasi dan cukup kompleks, juga adanya penintegrasian perihal nilai-niai pendidikan karakter terutama terkait dengan domain yang berbasis budaya lokal setempat (local culture), yakni Yogyakarta. Fenomena tersebut, kiranya sangat menarik untuk dikaji lebih lanjut, mengingat bahwa para siswa penyandang tunagrahita ringan tersebut, sebagaimana disampaikan di atas, mempunyai pelbagai keterbatasan yang kompleks, seperti kesulitan berpikir abstrak, berimajinasi, ingatan, berkonsentrasi, dan sulit menghubungan satu hal dengan lainnya (Fuller \& Sabatino, 1998; Mumpuniarti, 2006). Dengan adanya penelitian ini, diharapkan dapat didapatkan gambaran data yang komprehensif, perihal pengintegrasian nilai-nilai pendidikan karakter berbasis budaya lokal bagi siswa penyandang tunagrahita ringan, yang mungkin bisa dijadikan salah satu referensi penting bagi pengembangan model pendidikan sejenis di tempat lain yang relevan di masa mendatang.

\section{METODE}

Metode yang digunakan dalam penelitian ini adalah kualitatif- fenomenologis, dengan penekanan kajian pada domain tindakan sosial dan pengalaman subjek penelitian (Sullivan, 2009; Frost, Nollaig, 2011). Penelitian ini dilaksanakan di SLB Negeri 2 Yogyakarta, pada semester gasal tahun ajaran 2019/2020, khususnya pada fokus pembelajaran keterampilan kriya kayu.

Teknik pengumpulan data dalam penelitian ini mencakup wawancara, observasi, dan dokumentasi. Informan dalam konteks teknik wawancara dalam penelitian ini adalah guru keterampilan kriya kayu dan 4 siswa tunagrahita ringan jenjang SMP dan SMA. Teknik ini dilakukan untuk mengetahui tahap-tahap pembelajaran keterampilan kriya kayu dilakukan secara menyeluruh, dalam penelitian ini adalah: analisis kebutuhan, perencanaan, pelaksanaan, dan evaluasi pembelajaran. Observasi partisipatif dilakukan dengan ikut serta dalam proses pembelajaran keterampilan kriya kayu mulai dari awal hingga akhir, yang dilaksanakan sesuai jadwal mata pelajaran tersebut, yakni pada hari Senin, Selasa, dan Rabu. Dokumentasi dilakukan dengan mempelajari administrasi yang dibuat oleh guru, khususnya adalah analisis kebutuhan, RPP, dan evaluasi pem- 
belajaran. Selain itu, teknik ini juga digunakan untuk merekam dan mendokumentasikan hasil produk-produk keterampilan kriya kayu yang dibuat siswa. Ketiga teknik pengumpulan data tersebut, sekaligus juga difungsikan sebagai uji validitas data, yang menggunakan jenis tirangulasi, khususnya teriangulasi sumber dan triangulasi teknik (Patton, 2014).

Adapun teknis analisis data dalam penelitian ini yaitu Teknik analisis deskriptif kualitatif model interaktif dari Miles \& Huberman (1994). Teknik analisis ini mengikuti empat tahapan, yakni pengumpulan data, reduksi data, penyajian data, dan penarikan kesimpulan.

\section{HASIL DAN PEMBAHASAN}

\section{Hasil}

Sebagaimana telah disampaikan pada sajian sebelumnya, pada sajian awal perihal hasil penelitian ini, kiranya perlu disampaikan gambran singkat tentang latar (setting) penelitian tentang pengintegrasian nilai-nilai pendidikan karakter berbasis local culture pada pembelajaran keterampilan kriya kayu bagi siswa tunagrahita ringan ini, dilaksanakan di SLB Negeri 2 Yogyakarta. Sekolah ini berlokasi di Jl. Panembahan Senopati No. 46, Prawirodirjan, Kec. Gondomanan, Kota Yogyakarta, Daerah Istimewa Yogyakarta 55121. Sekolah ini mengelola pembelajaran mulai dari jenjang taman kanak-kanak sampai sekolah menengah atas.

Pembelajaran keterampilan kriya kayu dimulai jenjang SMPLB sampai SMALB. Pada saat penelitian ini dilaksanakan, pembelajaran dilaksanakan oleh siswa SMPLB, karena siswa kelas XII SMALB melaksanakan magang di dunia usaha. Rombongan belajar dalam pembelajaran dilaksanakan oleh 4 siswa laki-laki yang terdiri dari 3 siswa kelas VIII dan 1 siswa kelas IX. Pem- belajaran dilaksanakan sesuai jadwal adalah setiap hari Senin, Selasa, dan Rabu.

Kegiatan pembelajaran keterampilan kriya kayu dilaksanakan pada ruang khusus studio dan didukung dengan fasilitas yang sangat lengkap. Alat-alat praktik kriya kayu terdiri atas alat manual dan masinal. Selain itu, alat didukung dengan listrik yang memadai. Bahan-bahan untuk membuat produk kayu juga cukup lengkap mulai dari kayu, MDF, dan triplek. Sedangkan bahan pendukung seperti lem, paku, cat, dan bahan finishing juga tersedia dan siap pakai.

SLB Negeri 2 Yogyakarta menyediakan keterampilan kriya kayu termasuk muatan lokal potensi daerah sebagai salah satu pengembangan diri pilihan untuk tunagrahita ringan. Berdasarkan hasil observasi, dokumentasi, dan wawancara menunjukkan bahwa implementasi pembelajaran terbagi menjadi beberapa tahap, yaitu analisis kebutuhan, perencanaan pembelajaran, proses pembelajaran, dan evaluasi pembelajaran. Berikut ini adalah implementasi pengintegrasian pendidikan karakter berbasis local culture dalam pembelajaran keterampilan kriya kayu di SLB Negeri 2 Yogyakarta, yang disampaikan berdasarkan tahapan sebagaimana dimaksud.

\section{Analisis Kebutuhan}

Analisis kebutuhan pembelajaran keterampilan kriya kayu dengan pengintegrasian nilai-nilai pendidikan karakter berbasis local culture bagi siswa tunagrahita ringan ini, dilaksanakan di SLB Negeri 2 Yogyakarta, dilaksanakan pada awal sebelum rencana pembelajaran. Guru menggunakan metode wawancara, observasi, dan diskusi dengan guru kelas untuk analisis kebutuhan siswa yang mengikuti pembelajaran. Data yang disajikan pada analisis kebutuhan berupa kualitatif dan kuantitatif. Indika- 
tor pokok dalam analisis kebutuhan ini adalah kemampuan dasar, kemampuan khusus, hambatan, dan potensi siswa. Pengukuran kemampuan dasar dan kemampuan khusus dilakukan dengan memberikan nilai angka 1-4. Nilai tersebut, menunjukkan tingkatan siswa tidak mampu mengerjakan, siswa mampu mengerjakan dengan bantuan guru, siswa mampu mengerjakan dengan instruksi, dan siswa mampu mengerjakan secara mandiri. Pengukuran hambatan dan potensi ditampilkan dalam bentuk deskriptif. Tabel 1 dan Tabel 2 berikut ini adalah hasil analisis kebutuhan siswa tunagrahita dengan inisial BA, MR, $\mathrm{SD}$, dan $\mathrm{AR}$ yang mengikuti pembelajaran keterampilan kriya kayu serta hambatan dan potensinya.

\section{Tabel 1. Hasil Analisis Kebutuhan Siswa} pada Pembelajaran Keterampilan Kayu

\begin{tabular}{lcccc}
\hline \multicolumn{1}{c}{ Indikator } & \multicolumn{5}{c}{ Kemampuan Siswa } \\
& BA & MR & SD & AR \\
\hline Kemampuan dasar: & & & & \\
1. Menulis & 2 & 1 & 1 & 2 \\
2. Membaca & 3 & 2 & 1 & 1 \\
3. Menghitung & 2 & 2 & 2 & 2 \\
4. Menggambar & 2 & 2 & 3 & 2 \\
Kemampuan khusus: & & & & \\
1. Memotong & 3 & 4 & 4 & 2 \\
2. Mengelem & 2 & 3 & 3 & 2 \\
3. Merakit & 2 & 2 & 2 & 2 \\
4. Mengamplas & 3 & 3 & 4 & 4 \\
5. Mem-finishing & 1 & 2 & 4 & 1 \\
\hline
\end{tabular}

Tabel 2. Hambatan dan Potensi Siswa pada Pembelajaran Keterampilan Kayu

\begin{tabular}{lll}
\hline Nama Siswa & \multicolumn{2}{c}{ Indikator } \\
\cline { 2 - 3 } BA & $\begin{array}{l}\text { Gambatan } \\
\text { kaki gemetar saat bingung dan panik. }\end{array}$ & $\begin{array}{l}\text { Mampu membaca dengan lancar, sabar } \\
\text { saat memotong kayu dengan teknik skrol. }\end{array}$ \\
\hline MR & $\begin{array}{l}\text { Kesulitan mengikuti instruksi tanpa } \\
\text { contoh, tidak mampu membaca secara } \\
\text { lancar. }\end{array}$ & $\begin{array}{l}\text { Komunikatif dan bekerja sama dengan } \\
\text { baik, mampu membuat potongan kayu } \\
\text { dengan detil. }\end{array}$ \\
\hline SD & $\begin{array}{l}\text { Tuna laras dan tunagrahita ringan, sering } \\
\text { menganggu teman saat belajar. }\end{array}$ & $\begin{array}{l}\text { Mampu membuat produk secara mandiri } \\
\text { dan dapat berkreasi dengan arahan } \\
\text { dan petunjuk guru. }\end{array}$ \\
\hline \multirow{2}{*}{ AR } & $\begin{array}{l}\text { Pendiam, pasif, dan kurang komunikasi, } \\
\text { sulit untuk diajak bekerja sama. }\end{array}$ & $\begin{array}{l}\text { Tekun pada satu keahlian, yaitu mengam- } \\
\text { plas dan mendempul permukaan kayu de- } \\
\text { ngan baik. }\end{array}$ \\
\hline
\end{tabular}

\section{Perencanaan Pembelajaran}

Perencanaan pembelajaran keterampilan kriya kayu dengan pengintegrasian nilai-nilai pendidikan karakter berbasis local culture bagi siswa tunagrahita ringan ini, dilaksanakan di SLB Negeri 2 Yogyakarta, dibuat oleh guru mata pelajaran. Secara keseluruhan, rencana pembelajaran berupa rumusan Kompetensi Dasar dan Standar Kompetensi, Silabus, Rencana Pelaksanaan Pembelajaran, Program Semester, dan Program Tahunan. Guru merumuskan kompetensi berdasarkan hasil analisis kebutuhan.

Kompetensi yang diajarkan dalam pembelajaran ini adalah membuat produk kriya kayu dengan teknik skrol dalam dan skrol luar. Selanjutnya, guru membuat desain gambar kerja produk yang akan dibuat oleh siswa. Di samping itu, guru juga merencanakan pembelajaran dengan mengombinasikan kayu dengan resin. Pembagian jam belajar untuk keterampilan kayu adalah 26 jam pelajaran dalam satu minggu atau $60 \%$ dari 42 jam pelajaran. 


\section{Pelaksanaan Pembelajaran}

Pelaksanaan pembelajaran keterampilan kriya kayu dengan pengintegrasian nilai-nilai pendidikan karakter berbasis local culture bagi siswa tunagrahita ringan di SLB Negeri 2 Yogyakarta, dilaksanakan dengan 3 tahap, yaitu pembukaan, proses belajar, dan penutup. Berikut adalah tahap pelaksanaan pembelajaran sebagaimana dimaksud.

Pertama, pembukaan dilaksanakan mengawali pembelajaran dengan doa, presensi, apersepsi, dan penyampaian tujuan pembelajaran. Guru memimpin pembukaan pembelajaran dan memotivasi siswa untuk semangatdalam belajar.

Kedua, proses pembelajaran dilaksanakan dengan metode demonstrasi dan pendekatan project based learning. Guru memeragakan tahap-tahap pembuatan produk dan diikuti oleh siswa. Selanjutnya siswa praktik secara mandiri membuat produk dengan pengawasan dari guru. Apabila ada siswa yang tidak dapat melakukan tahap pembuatan produk dibantu oleh temannya. Selanjutnya siswa diarahkan pada tahap yang lain sesuai instruksi dan petunjuk guru.

Pembuatan produk dimulai dengan menempelkan gamabr pola pada kayu, selanjutnya memotong kayu dengan mesin skrol, dan merapikan potongan kayu. Pada tahap pembuatan resin guru menggunakan alat yang disederhankan agar siswa tidak perlu menghitung takaran resin. Siswa menuangkan resin pada permukaan kayu dan menunggu pengeringan resin. Kemudian siswa mengamplas dan meratakan permukaan produk dengan mesin amplas. Tahap terakhir adalah finishing dengan bahan kompon untuk mengkilatkan permukaan kayu dan resin. Pemasangan bingkai di- lakukan oleh guru untuk menyempurnakan produk.

Ketiga, penutup pembelajaran dilaksanakan dengan membersihkan alat dan ruangan secara menyeluruh. Siswa menggunakan penyedot debu untuk membersihkan alat dan lantai. Pada akhirnya guru mengakhiri pembelajaran dengan doa dan refleksi pembelajaran yang telah dilaksanakan.

Adapun terkait dengan gambaran proses pembelajaran, terutama dengan fokus pembuatan hiasan berbahan kayu dengan pengintegrasian nilai-nilai pendidikan karakter berbasis local culture bagi siswa tunagrahita ringan di SLB Negeri 2 Yogyakarta tersebut, sesuai dengan tahapannya mulai dari: pembuatan pola ornamen di kertas, pemindahan atau penempelan pola ke papan kayu, penggergajian kayu sesuai pola ornamen, pengamplasan, sampai finishing karya, sebagaimana dapat dilihat pada sajian gambar-gambar $1-7$ berikut.



Gambar 1. Pembuatan Pola Ornamen di Atas Kertas

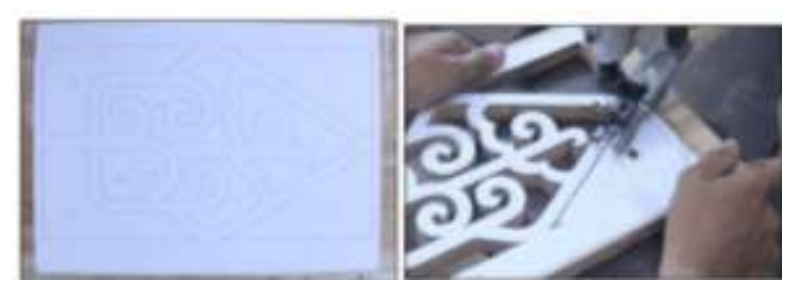

Sumber: Koleksi Penulis, 2020

Gambar 2. Penempelan Pola di Atas Papan Kayu dan Penggergajian Sesuai Pola 


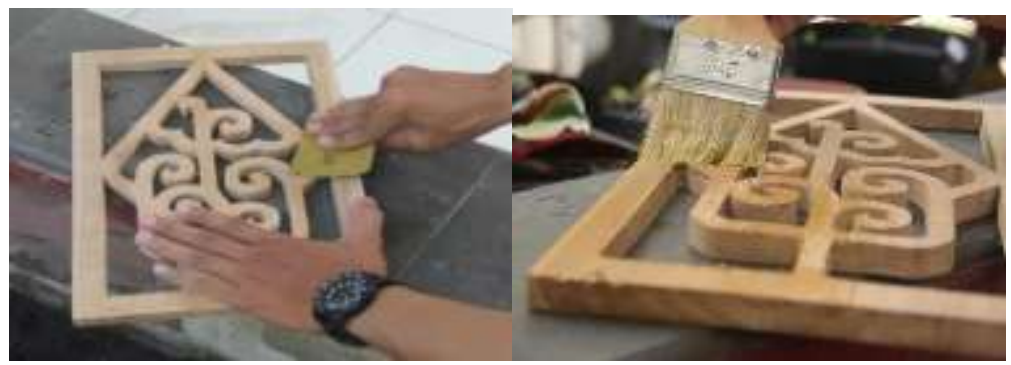

Gambar 3. Pengamplasan dan Finishing.

Sumber: Koleksi Penulis, 2020.

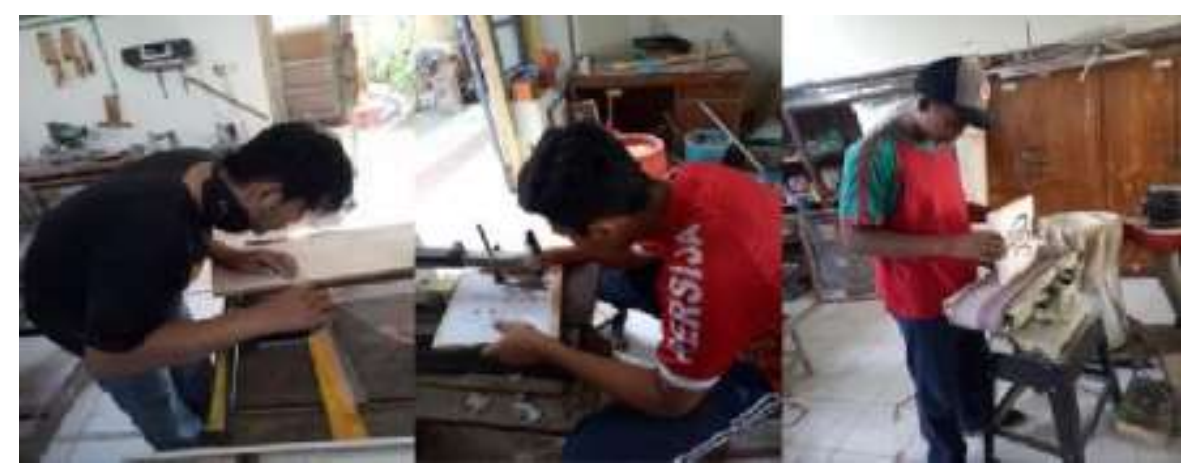

Gambar 4. Beberapa Aktivitas Proses Pembelajaran

Keterampilan Kriya Kayu SLB Negeri 2 Yogyakarta

Sumber: Koleksi Penulis, 2020

Sementara untuk hasil produk berupa hiasan pajang berbahan papan kayu yang dibuat dengan teknik skrol dalam dan teknik skrol luar dikombinasikan dengan resin, dengan menerapkan pelbagai ikon budaya lokal Yogyakarta, misalnya: gunungan, lambang kraton Yogyakarta, tugu golong-gilig Yogyakarta, sepeda onthel, dan motif batik kawung, beberapa di antaranya sebagaimana disajikan pada gambargambar berikut.

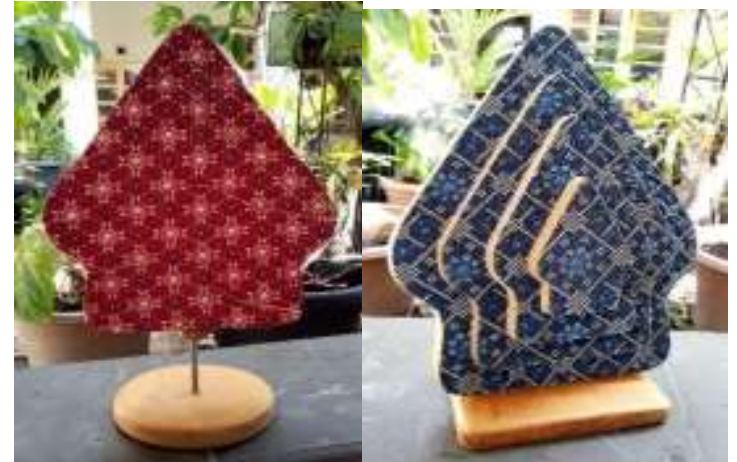

Gambar 5. Contoh Hasil Produk Siswa Tunagrahita Ringan SLB Negeri 2 Yogyakarta Bermuatan Local Culture dengan Ornamen Gunungan Sumber: Koleksi Penulis, 2020. 


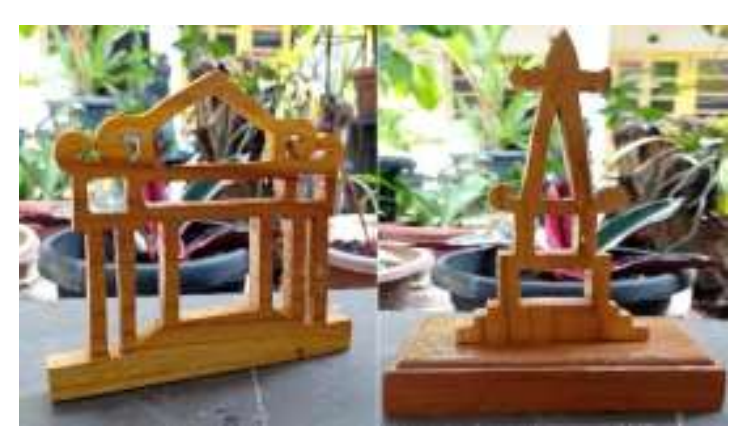

Gambar 6. Contoh Hasil Produk Siswa

Tunagrahita Ringan SLB Negeri 2

Yogyakarta Bermuatan Local Culture dengan Ornamen Lambang Kraton dan Tugu Yogyakarta

Sumber: Koleksi Penulis, 2020

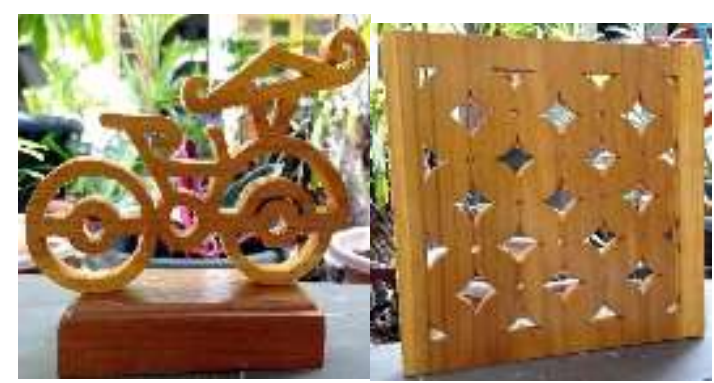

Gambar 7. Contoh Hasil Produk Siswa

Tunagrahita Ringan SLB Negeri 2

Yogyakarta Bermuatan Local Culture dengan Ornamen Sepeda Onthel dan Kawung

Sumber: Koleksi Penulis, 2020

\section{Evaluasi Pembelajaran}

Evaluasi pembelajaran pembuatan hiasan berbahan kayu dengan pengintegrasian nilai-nilai pendidikan karakter berbasis local culture bagi siswa tunagrahita ringan di SLB Negeri 2 Yogyakarta tersebut, dilaksanakan dengan penilaian proses dan penilaian produk. Penilaian proses dilaksanakan dengan pengamatan saat pembelajaran praktik. Penilaian proses meliputi sikap, pengetahuan, dan keterampilan. Sementara itu, penilaian produk yang dihasilkan siswa, terutama berfokus pada aspek estetika dan proporsi produk. Dalam evaluasi pembelajaran ini lebih menekankan pada penilaian proses dengan prosesntase $60 \%$ sedangkan penilaian produk $40 \%$. Tabel 3 berikut ini adalah rekap penilaian produk berupa hiasan pajang berbahan papan kayu, dengan pengintegrasian nilai-nilai pendidikan karakter berbasis local culture bagi siswa tunagrahita ringan di SLB Negeri 2 Yogyakarta.

Tabel 3. Evaluasi Pembelajaran Keterampilan Kayu dengan Peningtegrasian Pendidikan Karakter Berbasis Local Culture

\begin{tabular}{|c|c|c|c|}
\hline \multirow{2}{*}{ No. Nama Siswa } & \multicolumn{2}{|c|}{ Nilai } & \multirow{2}{*}{$\begin{array}{l}\text { Nilai } \\
\text { Akhir }\end{array}$} \\
\hline & Proses & Produk & \\
\hline 1. $\mathrm{BA}$ & 87 & 84 & 85,8 \\
\hline 2. $\mathrm{MR}$ & 83 & 86 & 84,2 \\
\hline 3. $\mathrm{SD}$ & 78 & 92 & 83,6 \\
\hline 4. $\mathrm{AR}$ & 84 & 85 & 84,4 \\
\hline
\end{tabular}

\section{Pembahasan}

Berdasarkan data hasil peneltian sebagaimana telah disampaikan di atas, dapat disampaikan bahwa implementasi pembelajaran keterampilan kriya kayu, dengan pengintegrasian nilai-nilai pendidikan karakter berbasis local culture bagi siswa tunagrahita ringan di SLB Negeri 2 Yogyakarta dapat berjalan dan berhasil dengan baik. Hal tersebut disebabkan, di samping didukung oleh peralatan yang cukup lengkap yang dimiliki oleh sekolah ini, juga berkat tata kelola pembelajarannya yang sangat baik, baik di tingkat analisis kebutuhan, perencanaan, pelaksanaan, dan juga evaluasinya.

Pembelajaran keterampilan kriya kayu dengan pengintegrasian nilai-nilai pendidikan karakter berbasis local culture bagi siswa tunagrahita ringan di SLB Negeri 2 Yogyakarta, dimulai dengan kegiatan analisis kebutuhan yang hasilnya sangat memadai. Hal tersebut tidak dapat dilepaskan dari komitmen dan kemampuan guru dalam melakukan kinerja diagnostik dan analisis kebutuhan, yang memang menjadi 
keharusan dalam implementasi pembelajaran inklusif di sekolah (Mumpuniarti \& Lestari, 2018).

Kegiatan analisis kebutuhan tersebut dilakukan untuk menyaring kemampuan tunagrahita ringan; pengklasifikasian, penempatan, dan penentuan program; penentuan arah dan kebutuhan; pengembangan program pembelajaran yang diindividualkan atau biasa disebut IEP (individualized educational program); dan menentukan strategi pembelajaran yang relavan (Amin, 1995). Hasil analisis kebutuhan tersebut, kemudian dijadikan pedoman bagi guru untuk mengembangkan pembelajaran secara optimal, khususnya membuat produk kriya kayu dengan pengintegrasian nilainilai pendidikan karakter berbasis local culture.

Hasil analisis kebutuhan yang telah dilakukan olah guru, menunjukkan bahwa kemampuan siswa membutuhkan petunjuk dan bantuan dari guru. Secara keseluruhan, hasil analisis kebutuhan tersebut didapatkan untuk menggali dan mengidentifikasi pelbagai potensi, kebutuhan, serta kekurangan siswa. Dari hasil analisis kebutuhan didapatkan di antaranya adalah, bahwa kemampuan dasar siswa dalam belajar masih banyak terkendala untuk berkaitan dengan kemampuan kognitif, belum dapat membaca dan menulis dengan baik. Demikian juga halnya untuk kategori kemampuan khusus terkait dengan konteks fokus pembuatan karya keterampilan kayu, mulai dari membuat pola, memotong, sampai finishing, juga menunjukkan hasil bahwa siswa masih banyak memiliki kendala. Berdasarkan hasil analisis kebutuhan tersebut, menunjukkan bahwa siswa belum mampu membuat produk secara mandiri, mereka butuh penuh arahan dan bantuan dari guru untuk belajar.

Berkaitan dengan proses selanjutnya, yakni pembelajaran keterampilan kriya kayu dengan pengintegrasian nilai-nilai pendidikan karakter berbasis local culture bagi siswa tunagrahita ringan di SLB Negeri 2 Yogyakarta, menggunakan metode demonstrasi dan project based learning. Metode demonstrasi untuk tunagrahita ringan dijalankan terutama untuk memperlihatkan atau mempraktikkan suatu proses cara kerja secara prosedural terkait dengan alat untuk pembuatan benda tertentu (Browder \& Minarovic, 2000; Kemis, 2013). Guru dalam hal ini, dituntut aktif untuk memperagakan dan mengawasi siswa saat praktik belajar menggunakan alat.

Sedangkan untuk pendekatan project based learning digunakan untuk meningkatkan kemampuan berpikir siswa agar lebih kritis dan kreatif. Hal ini sejalan dengan penelitian yang dilakukan oleh Eldiva \& Azizah (2018) yang menunjukkan bahwa project based learning dapat meningkatkan keterampilan berpikir kritis siswa tunagrahita. Model project based learning untuk tunagrahita disusun secara sederhana, dimulai dengan tahap yang mudah menuju tahap yang kompleks.

Secara khusus terkait dengan konten pembelajaran, guru melakukan inovasi pengembangan dalam belajar untuk pembuatan produk keterampilan berbahan kayu, yakni dengan penggunaa inovasi bahan resin untuk meningkatkan kualitas produk yang lebih kreatif. Resin merupakan bahan yang menarik untuk campuran kayu. Warnanya yang bersifat transparan menimbulkan kesan unik dan elegan pada produk. Diharapkan kombinasi bahan resin ini, membuat suasana belajar menjadi lebih menyenangkan, yang dikarenakan siswa diperkenalkan hal-hal yang baru dan lebih memungkinkan untuk eksploratif hasil produknya. Suasana belajar menyenangkan dapat menimbulkan minat belajar siswa 
(Wakiman, 1998; Killen, 2007). Fenomena menyenangkan dalam konteks pembelajaran keterampilan kriya kayu dengan pengintegrasian nilai-nilai pendidikan karakter berbasis local culture bagi siswa tunagrahita ringan di SLB Negeri 2 Yogyakarta, dapat dilihat di samping sejak tahap awal pembelajaran yang sangat bersemangat, juga terutama ketika pada moment mencampur warna resin yang akan digunakan untuk melapisi produk hiasan berbahan papan kayu sesuai dengan keinginan mereka.

Berkat antusiasme yang sangat tinggi dari para siswa, dalam proses pembuatan produk benda hias tersebut, guru merencanakan penyelesaian dalam waktu 3 bulan, tetapi ternyata dapat diselesaikan dalam waktu 2 bulan saja. Meskipun dalam setiap proses pembuatan produk tersebut, acapkali kurang sesuai dengan apa yang direncanakan guru. Oleh karena itu, pada saat praktik berkarya guru selalu mengawasi dan mengarahkan siswa agar tidak kesulitan dalam berkarya. Bahkan guru juga terkadang terlibat misalnya membantu membenahi desain karya agar lebih memungkinkan dikerjakan atau diselesaikan oleh siswa. Hal tersebut dilakukan dengan menyesuaikan kemampuan siswa agar bekerja secara mandiri. Hasil karya tunagrahita tidak dapat diprediksi penyelesaiannya dan hasilnya akhirnya juga tidak dapat sesempurna yang diharapkan sehingga sangat diperlukan pelbagai penyesuaian atau bantuan dari para pengajarnya, yang menyesuaikan kemampuan mereka. Guru karenanya, sangat disarankan melakukan pelbagai kegiatan yang diistilahkan sebagai "insidental instruksional" dengan mengambil keputusan secara cepat dan cerdas sebagai bentul layanan pembelajaran tunagrahita, karena pelbagai faktor keterbatasan yang dimilikinya (Ishartiwi, 2012).

Kemudian terkait dengan tahapan evaluasi pembelajarannya, dalam konteks ini dimaksudkan untuk mengukur kemampuan siswa ditinjau dari kategori proses dan hasilnya. Evaluasi tersebut dilakukan didasarkan pada analisis kebutuhan awal pembelajaran. Perkembangan kemampuan siswa merupakan tujuan utamanya. Evaluasi ini juga sebagai pijakan analisis kebutuhan pembelajaran selanjutnya. Amin (1998) menyatakan analisis kebutuhan pada saat dan setelah tunagrahita diberikan pelajaran diperlukan untuk merancang program selanjutnya. Dalam pembelajaran keterampilan kayu dapat digunakan untuk merumuskan rancangan produk yang baru yang mengoptimalkan kemandirian tunagrahita.

Evaluasi pembelajaran yang terkait dengan domain proses dalam konteks ini, dilakukan guru dengan mengamati proses praktik berkarya siswa meliputi sikap, pengetahuan, dan keterampilan. Pada saat pembelajaran keterampilan kriya kayu dengan pengintegrasian nilai-nilai pendidikan karakter berbasis local culture bagi siswa tunagrahita ringan di SLB Negeri 2 Yogyakarta, ternyata ada satu siswa berinisial SD, yang sering melakukan pelanggaran, misalnya berupa penyimpangan perilaku, seperti sering absen, suka mengejek siswa lain, tidak bersikap sopan pada guru, kurang jujur, melakukan kekerasan fisik pada teman, dan tidak mau bekerja sama. Namun, pada saat berkarya, ia mampu mengerjakan produk dengan cepat sesuai yang gambar kerja atau desain yang telah disiapkan. Hasil akhirnya juga lebih baik dibandingkan dengan yang lainnya. Hal ini menunjukkan setiap individu tunagrahita memiliki kekurangan dan kelebihan masing-masing.

Terkait dengan hal tersebut, perhatian khusus guru dalam penggunaan pembelajaran dengan kombinasi pendekatan 
klasikal dan personal menjadi amat penting dijalankan (Obiakor, Bakken, \& Rotatori, 2010). Terutama dalam rangka membentuk sikap kerja yang baik, komunikatif, kerjasama, dan jujur sangat perlu dilakukan. Guru perlu memodifikasi pembelajaran yang membiasakan pengembangan karakter tersebut. Walaupun anak tunagrahita memiliki keterbatasan kognitif dalam belajar dan gangguan perilaku, melalui program pembiasaan, diharapkan mereka mampu berubah secara bertahap untuk menjadi pribadi yang lebih baik.

Manakala dilihat dari sudut pandang yang komprehensif, baik dari sisi proses maupun juga hasilnya berua produk karya hiasan berbahan dari papan kayu sebagaimana telah disampaikan di atas, bahwa secara umum, pengintegrasian nilai-nilai pendidikan karakter berbasis local culture pada pembelajaran keterampilan kriya kayu bagi penyandang tunagrahita ringan di SLB Negeri 2 Yogyakarta tersebut, dapat dikatakan berhasil dengan sangat baik. Perihal karyakarya hiasan berbahan dari kayu dengan pelbagai ikon budaya lokal Yogyakarta, misalnya: gunungan, lambang kraton Yogyakarta, tugu golong-gilig Yogyakarta, sepeda onthel, dan motif batik kawung tersebut, betapa menjadi sebentuk pencapaian pembelajaran yang mempunyai signifikansi tinggi, bukan hanya semata-mata bagi kepentingan si pelaku pembelajaran itu sendiri, yakni para penyandang tunagrahita ringan, melainkan yang tak kalah penting adalah juga bagi pengembangan, pelestarian, dan penghargaan atas nilai-nilai identitas budaya bangsa.

Sebagaimana diketahui bahwa entitas identitas sebuah bangsa itu memang secara eksistensial senantiasa dikonstruksi oleh pelbagai entitas kultur partikular yang sifatnya lokal. Pandangan tersebut sejalan dengan kosep identitas itu sendiri, yang memang erat berkelindan dengan apa yang diistilahkan dalam khazanah arkeologi sebagai kearifan budaya lokal (local wisdom/ local genius). Konsep ini pertama kali dikenalkan oleh arkeolog H.G. Quaritch Wales pada tahun 1948) dalam tulisan berjudul “The Making of Greater India: A Study in South-East Asia Culture Change", dalam Journal of the Royal Asiatic Sociaty (Bosch, 2013:4).

Munculnya istilah local genius oleh Wales ini, sebagai respons atas pandangan yang dikemukakan F.D.K. Bosch pada tahun 1946 dalam pidato pengukuhannya sebagai Guru Besar Universitas Leiden, yang berjudul Het Vraagstuk van de Hindoekolonisatie van den Archipel, di mana Bosch menekankan pentingnya kepemilikan ciri khas kebudayaan yang ada dalam setiap diri bangsa. Ciri-ciri khas atau yang biasa disebut sebagai "pribumi" itulah, yang oleh Wales (Poespowardojo, 1986:30) diistilahkan local genius, yang di dalamnya terkandung makna sebagai "basic personality of each culture", atau ungkapan Anderson (2002:10), yakni local genius diartikan sebagai "cultural artefacts of a particular kind".

Mengingat posisi strategisnya local genius bagi pembangunan identitas sebuah bangsa, karenanya kehadirannya menjadi sebentuk nilai-nilai pendidikan karakter yang penting dan strategis diajarkan bagi peserta didik, termasuk dalam konteks ini adalah siswa penyandang disabilitas kategori tunagrahta ringan, juga menemukan relevasi signifikansinya. Hal tersebut disebabkan, setiap keberadaan atau representasi karya seni, termasuk karya seni rupa dalam wujud hiasan berbahan kayu tersebut, pada hakikatnya sebagaimana disampaikan oleh Yuniawan \& Marzuki (2020), bukan semata berkaitan dengan dimensi estetis atau keindahannya semata, melainkan lebih dari itu, juga potensial mengandung 
nilai-nilai pendidikan karakter yang tinggi signifikansinya, bukan hanya bersifat individu, tetapi juga bagi sebuah bangsa.

\section{SIMPULAN}

Berdasarkan hasil penyajian data dan pembahasan dapat disimpulkan bahwa pelaksanaan pembelajaran keterampilan kriya kayu pada anak tunagrahita dengan pengintegrasian nilai-nilai pendidikan karakter berbasis local culture di SLB Negeri 2 Yogyakarta, dapat disampaikan berhasil dengan sangat baik. Keberhasilan pembelajaran tersebut, tak bisa dilepaskan dari keberhasilan dalam pengelolaan pembelajaran secara utuh, mulai dari tahapan: analisis kebutuhan, perencanaan pembelajaran, pelaksanaan, dan sampai evaluasi pembelajaran. Kesimpulan dari penelitian ini menggambarkan analisis kebutuhan dilaksanakan dengan metode wawancara, observasi dan diskusi dengan guru kelas, hasil analisis kebutuhan berhasil menggali dan mengidnetifikasi potensi, kebutuhan, dan kekurangan siswa. Perencanaan pembelajaran dirumuskan dengan menyesuaikan kemampuan siswa dan guru menentukan teknik skrol untuk membuat produk hiasan dikombinasikan dengan bahan resin. Pelaksanaan pembelajaran membuat hiasan berikonkan ornamen lokal khas Yogyakarta tersebut, membutuhkan waktu yang lebih cepat dari perkiraan, metode yang digunakan guru adalah demonstrasi dengan model project based learning. Evaluasi pembelajaran menekankan pada penilaian proses dari pada produk.

Berkat proses pembelajaran yang dijalankan dengan memperhatikan semaksimal mungkin di setiap tahapan dan terutama disesuaikan dengan potensi, kebutuhan, dan kekurangan yang dimiliki oleh masing-masing siswa tunagrahita ringan di SLB Negeri 2 Yogyakarta tersebut, akhir- nya mampu menghasilkan produk yang bukan hanya kreatif, melainkan mempunyai nilai kulturasi yang sangat tinggi bagi pembangunan jiwa nasionalisme bagi para siswa, termasuk juga penyandang tunagrahita. Pelbagai ikon lokalitas budaya Yogyakarta (misanya gunungan, lambang kraton Yogyakarta, tugu golong-gilig Yogyakarta, sepeda onthel, dan motif batik kawung), yang dikenalkan dan dipraktikkan dalam wujud pembuatan karya hiasa dari kayu sebagaimana dimakusd pada diametrikal tertentu, juga mempunyai nilai signifikansi yang tinggi terutama terkait dengan pembangunan politik identitas bukan hanya lokalitas melainkan juga nasionalitas sebuah bangsa.

\section{UCAPAN TERIMA KASIH}

Ucapan terima kasih juga disampaikan kepada Redaktur Jurnal Pendidikan Karakter atas saran dan masukan untuk perbaikan artikel ini, sehingga kualitasnya menjadi lebih baik dan layak untuk diterbitkan.

\section{DAFTAR PUSTAKA}

Aguilar, M.J.C. (2000). Culture and power: Challenging discourses. València, Spanish: Universitat de València.

Amin, M. (1995). Ortopedagogik Anak Tunagrahita. Jakarta: Departemen Pendidikan dan Kebudayaan.

Anderson, B. (2002). Imagined communities (Komunitas-komunitas terbayang). Yogyakarta: INSIST Bekerja sama dengan Pustaka Pelajar.

Anggraini, N. (2016). Vocational skills development for people with intellectual disabilities by institution BBRSBG Kartini Temanggung Central Java. Proceedings The $2^{\text {nd }}$ International Multidisciplinary Conference, Universitas $\mathrm{Mu}$ - 
hammadiyah Jakarta, Indonesia, November 2016 (872-875).

Arnott, M. \& Ozga, J. (2010). Education and nationalism: The discourse of education policy in Scotland. Discourse: Studies in the Cultural Politics of Education, 31(3), 335-350, DOI: 10.1080/01596301003786951.

Astati. (2001). Persiapan pekerjaan penyandang tunagrahita. Bandung: CV Pandawa.

Ayres, K.M., Lowrey, K.A., Douglas, K.H., \& Sievers, C. (2011). I can identify saturn but I can't brush my teeth: What happens when the curricular focus for students with severe disabilities shifts. Education and Training in Autism and Developmental Disabilities, 46 (1), 11-21. Retrieved from https://www.jstor.org/stable/23880027.

Berkson, G. (2013). Children with handicaps: A review of behavioral research. London: Routledge.

Bosch, F.D.K. (2013). Selected studies in Indonesian archaeology. Berlin/Heidelberg. Germany: Springer.

Broman, S.H., Nichols, P.L., Shaughnessy, P., \& Kennedy, W. (2013). Retardation in young children: a developmental study of cognitive deficit. London: Routledge.

Browder, D.M. \& Minarovic, T.J. (2000). Utilizing sight words in self-instruction training for employees with moderate mental retardation in competitive jobs. Education and Training in Mental Retardation and Developmental Disabilities, 35(1), 78-89. Retrieved from https://www.jstor.org/stable/23879709.

Chauvin, L.O. (2000). Education for the future: environment and sustainable deve- lopment in Peru. London: CIIR (Chatolik Institute in International Relations) Press.

Davis, A.S. \& D'Amato, R.C. (2010). Handbook of pediatric neuropsychology. New York: Springer Publishing Company.

DeVereaux, C. \& Griffin, M. (2016). Narrative, identity, and the map of cultural policy: once upon a time in a globalized world. London: Routledge.

Efendi, M. (2009). Pengantar psikopedagogik anak berkelainan. Jakarta: PT Bumi Aksara.

Eldiva, F.T. \& Azizah, N. (2018). Project based learning in improving critical thinking skill of children eith special needs. Proceedings International Conference on Special and Inclusive Education (ICSIE, 2018). DOI: https://doi.org/10.2991/icsie-18.2019.64.

Fuller, C.G., \& Sabatino, D.A. (1998). Diagnosis and treatment considerations with comorbid developmentally disabled populations. Journal of Clinical Psychology, 54(1), 1-10. DOI: https://doi.org/10.1002/(SICI)109 7-4679(199801)54:1<1::AID- JCLP1>3.0.CO;2-X.

Gladfelter, A. \& Barron, K.L. (2020). How children with autism spectrum disorder, developmental language disorder, and typical language learn to produce global and local semantic features. Brain Sciences, 10(4), 230-249. DOI: https://doi.org/10.3390/brainsci10 040231.

Huang, W. \& Cuvo, A.J. (1997). Social skills training for adults with mental retardation in job-related settings. Behavior Modification, 21(1), 3-44. DOI: https://doi.org/10.1177/01454455 970211001. 
Ishartiwi. (2012). Kompetensi guru pendidikan khusus dan model pengembangannya dalam upaya peningkatan kualitas generasi bangsa penyandang difabel. Jurnal Pendidikan Khusus, 9(1), 1-11.DOI: https://doi.org/10.21831/jpk.v9i1. 6724.

Kementerian Pendidikan dan Kebudayaan. (2012). Integrasi pendidikan karakter dalam pembelajaran bagi peserta didik tunagrahita. Jakarta: Kemendikbud Direktorat PKLK.

Kemis. (2013). Pendidikan anak berkebutuhan khusus tunagrahita. Jakarta Timur: PT. Luxima Metro Media.

Killen, R. (2007). Teaching strategies for outcomes-based education. Cape Town: Juta and Company Ltd.

Lestari, S. (2012). Pengelolaan kurikulum muatan lokal (KML) Bahasa Inggris SD Negeri se-Kecamatan Gondokusuman Yogyakarta. Jurnal Penelitian Ilmu Pendidikan, 2(2), 66-73. DOI: https:// doi.org/10.21831/jpipfip.v5 i2. 4754 .

Lubis, A.M. Kasih, I. \& Simatupang, N. (2019). Implementation of physical education learning in down syndrome students at SLB YPAC Medan. Proceedings of the 4th Annual International Seminar on Transformative Education and Educational Leadership (AISTEEL 2019). Retrieved from https://www.atlantis-press.com/ proceedings/aisteel- 19/125928406.

Lynn, R. (2001). Eugenics: A reassessment. California: Greenwood Publishing.

Mastiani, E. \& Suwandari, L. (2017). Work skills program through apprenticeship program for children with mild mental retardation. PEOPLE: International Journal of Social Sciences, 3(3),
376-391. DOI: https://doi.org/10.20319/pijss.2017.33.376391.

Miles, M.B. \& Huberman, A.M. (1994). Qualitative data analysis: An expanded sourcebook. Thousand Oaks, CA: Sage Publication.

Mumpuniarti. (2006). Manajemen pembinaan vokasional bagi tunagrahita di sekolah khusus tunagrahita. Jurnal Pendidikan Khusus, 2(2), 1-17. DOI: https:/ / doi.org/10.21831/jpk.v2i2.979.

Mumpuniarti \& Lestari, P.H.K. (2018). Kesiapan guru sekolah reguler untuk implementasi pendidikan inklusif. Jurnal Pendidikan Khusus, 14(2), 57-61. DOI: https://doi.org/10.21831/jpk.v14i2.25167.

Nollaig, F. 2011. Qualitative research methods in psychology: combining core approaches: from core to combined approaches. New York: McGraw- Hill Education.

Obiakor, F.E., Bakken, J.P. \& Rotatori, A.F. (Eds.). (2010). Current issues and trends in special education: identification, assessment and instruction. Bingley, UK: Emerald Group Publishing.

Patton, M.Q. (2014). Qualitative research $\mathcal{E}$ evaluation methods: integrating theory and practice. Thousand Oaks, CA: Sage Publication.

Poespowardojo, S. (1986). Pengertian local genius dan relevansinya dalam modernisasi. Dalam Ayatrohaedi (Ed.), Kepribadian Budaya Bangsa (Local Genius). Jakarta: Pustaka Jaya.

Poole, R. (2012). Nation and identity. London: Routledge.

Ricci, C. \& Pritscher, C.P. (2015). Holistic pedagogy: the self and quality willed learning. Berlin, Germany: Springer. 
Robertson, R. \& White, K.E. (2003). Globalization: Culture and identity. London: Taylor \& Francis.

Schwitzer, A.M. \& Rubin, L.C. (2012). Diagnosis and treatment planning skills for mental health professionals: A popular culture casebook approach. Thousand Oaks, CA: Sage Publication.

Shi, J. (2013). Free trade and cultural diversity in international law. London: Bloomsbury Publishing.

Smith, M.B., Ittenbach, R.F. \& Patton, J.R. (2002). Mental retardation. $6^{\text {th }} \mathrm{Ed}$. New Jersey: Merrill Prentice Hall.

Soldatic, K, \& Grech, S. 2017. Disability and colonialism: (Dis)encounters and anxious intersectionalities. London: Routledge.

Stebnicki, M.A., Marini, I, Noreen M., \& Graf, N.M. (2011). Psychosocial aspects of disability: Insider perspectives and strategies for counselors. New York: Springer Publishing Company.

Steger, M., Battersby, P. \& Siracusa, J. (Eds.) (2014). The sage handbook of globalization. Thousand Oaks, CA: Sage Publication.

Stevens, A. (2004). Health care needs assessment: The epidemiologically based needs assessment reviews, Volume 2. Abingdon, United Kingdom: Radcliffe Publishing.

Sudartini, S. (2012). Inserting local culture in English language teaching to promote character education. Jurnal Pendidikan Karakter, 1(1), 45-54. DOI: https: // doi.org/10.21831/jpk.v0i1.1451.

Sullivan, L.E. (2009). The sage glossary of the social and behavioral sciences. Thousand
Oaks, CA: Sage Publication.

Wahyuni, N. (2018). Peran pendidikan vokasi bagi anak berkebutuhan khusus dalam menghadapi tantangan zaman. Jurnal Keluarga, 4(2), 137-147. DOI: http://dx.doi.org/10.30738/keluarg a.v4i2.5173.

Wakiman. (1998). Menumbuhkan kesenangan belajar matematika melalui permainan. Jurnal Kependidikan, 2(28), 211-222. DOI: https://doi.org/10.21831/jk.v28i2. 5047.

Werry, J.S \& Aman, M.G. (2013). Practitioner's guide to psychoactive drugs for children and adolescents. Berlin: Springer Science \& Business Media.

Wijaya, A. (2013). Teknik mengajar siswa tunagrahita. Yogyakarta: Imperium.

Yama, D. (2015). The revitalization policy of character-education in terms of strengthening the concept of nationalism. International Journal of Education, 8(2), 103-114. Retrieved October 10, 2020 from https://www.learntechlib.org/p/20 8909/.

Yuniawan, H.B. \& Marzuki. (2020). Nilainilai pendidikan karakter pada makna lukisan Petruk Dadi Ratu, Semare Kaling-Kalingan Mega, karya Subandi Giyanto. Jurnal Pendidikan Karater, 10(1), 49-68. DOI:https://doi.org/10.21831/jpk.v10i1.26189.

Zhuojun, W. \& Hualing, H. (2014). National identity in the era of globalization: Crisis and reconstruction. Social Sciences in China, 35:2, 139-154. DOI: https://doi.org/10.1080/02529203. 2014.900889. 